\title{
Effect of Aspirin on Cell Growth of Human MG-63 Osteosarcoma Line
}

\author{
E. De Luna-Bertos, ${ }^{1}$ J. Ramos-Torrecillas, ${ }^{1}$ O. García-Martínez, ${ }^{1}$ \\ L. Díaz-Rodríguez, ${ }^{1}$ and C. Ruiz ${ }^{1,2}$ \\ ${ }^{1}$ Biomedical Group (BIO277), Department of Nursing, Faculty of Health Sciences, University of Granada, 18071 Granada, Spain \\ 2 Institute of Neuroscience, University of Granada, 18071 Granada, Spain
}

Correspondence should be addressed to L. Díaz-Rodríguez, cldiaz@ugr.es

Received 11 October 2011; Accepted 22 December 2011

Academic Editor: Richard D. Byrne

Copyright ( 2012 E. De Luna-Bertos et al. This is an open access article distributed under the Creative Commons Attribution License, which permits unrestricted use, distribution, and reproduction in any medium, provided the original work is properly cited.

\begin{abstract}
Nonsteroidal anti-inflammatory drugs (NSAIDs) are commonly used in bone tissue repair treatment for their pharmacological action. The objective of this study was to determine the effect of aspirin, on osteoblast growth, using MG63 cell line as osteoblast model. MTT spectrophotometry results showed that 20,100, and $1000 \mu \mathrm{M}$ aspirin doses have an inhibitory effect on growth. Cell cycle analysis revealed that aspirin doses of 100 and $1000 \mu \mathrm{M}$ arrest the cell cycle in phase GO/G1. Parallel apoptosis/necrosis studies showed no changes in comparison to control cells after treatment with 1 or $10 \mu \mathrm{M}$ aspirin but a significantly increased percentage of cells in apoptosis at doses of 20,100 , and $1000 \mu \mathrm{M}$. We highlight that treatment of osteoblast-like cells with $1000 \mu \mathrm{M}$ aspirin increased not only the percentage of cells in apoptosis but also the percentage of necrotic cells, which was not observed in aspirin treatments at lower doses.
\end{abstract}

\section{Introduction}

Nonsteroidal anti-inflammatory drugs (NSAIDs) are widely used in orthopaedic surgery and traumatology to reduce pain and inflammation. Animal and cell culture studies have shown that some NSAIDs have an adverse effect on bone tissue through regeneration delay [1-6].

The mechanism by which NSAIDs exert their action on cell growth is under debate. Some authors cite the capacity of NSAIDs to inhibit synthesis of prostaglandin (PG), a molecule that is synthesized by osteoblasts and autocrinally favours their growth $[7,8]$. Others propose that the drug has a direct effect on the cell cycle based on in vitro findings that therapeutic doses of ketorolac, indomethacin, or diclofenac induce cell death in osteoblast cultures from rat foetal calvaria and may suppress bone formation and impair bone remodelling by arresting cell cycle in phase $\mathrm{G}_{0} / \mathrm{G}_{1}[9,10]$.

Different NSAIDs were recently reported to affect osteoblast proliferative capacity and modulate other features of this cell population, including differentiation, antigenic profile, and phagocytic capacity $[11,12]$. However, Arpornmaeklong et al. [13] found that indomethacin and celecoxib inhibit cell growth but have a less clear effect on cell differentiation as determined by alkaline phosphatase and osteocalcin synthesis.

Acetylsalicylic acid (aspirin) is very frequently administered for its anti-inflammatory, antipyretic, antiaggregant, and analgesic properties. However, in contrast to other NSAIDs, few data are available on its effects on bone tissue or on osteoblasts, the cells responsible for bone formation and regeneration. Therefore, the objective of this study was to analyse the effect of aspirin at different doses on osteoblast cell growth, using the human MG63 osteosarcoma cell line.

\section{Materials and Methods}

2.1. Cell Culture. The human MG-63 osteosarcoma cell line was purchased from American Type Cultures Collection (ATCC, Manassas, VA) and maintained as described by Díaz-Rodríguez et al. [14] in Dulbecco's-modified Eagle medium (DMEM; Invitrogen Gibco Cell Culture Products, Carlsbad, CA) with $100 \mathrm{IU} / \mathrm{mL}$ penicillin (Lab Roger SA, Barcelona, Spain), $50 \mu \mathrm{g} / \mathrm{mL}$ gentamicin (Braum Medical SA, Jaen, Spain), $2.5 \mu \mathrm{g} / \mathrm{mL}$ amphotericin B (Sigma, St Louis, 
MO, USA), 1\% glutamine (Sigma, St Louis, MO, USA), and 2\% HEPES (Sigma), supplemented with 10\% foetal bovine serum (FBS) (Gibco, Paisley, UK). Cultures were kept at $37^{\circ} \mathrm{C}$ in a humidified atmosphere of $95 \%$ air and $5 \% \mathrm{CO}_{2}$. Cells were detached from the culture flask with a solution of $0.05 \%$ trypsin (Sigma) and $0.02 \%$ ethylene diamine tetraacetic acid (EDTA) (Sigma) and then washed and suspended in complete culture medium with 10\% FBS.

2.2. Cell Proliferation. Cell proliferation was determined by the MTT method. Osteoblasts were seeded at $1 \times 10^{4}$ cells/mL per well into a 96-well plate without FBS and cultured at $37^{\circ} \mathrm{C}$ for 24 hours. Subsequently, the medium was replaced with DMEM containing aspirin at a dose of 0 , $0.1,1,10,20,100$, or $1000 \mu \mathrm{M}$. At the end of treatments, the medium was replaced with DMEM containing $0.5 \mathrm{mg} / \mathrm{mL}$ MTT (Sigma) and incubated for 4 hours. Cellular reduction of the MTT tetrazolium ring resulted in the formation of a dark-purple water-insoluble deposit of formazan crystals. After incubation, the medium was aspirated and DMSO was added to dissolve the formazan crystals. Absorbance was measured at $570 \mathrm{~nm}$ with a spectrophotometer (Sunrise, Tecan, Männedorf, Switzerland).

2.3. Cell Cycle. Cultured human MG-63 osteosarcoma cells treated with $1,10,20,100$, or $1000 \mu \mathrm{M}$ of aspirin and untreated control cells were detached from the culture flask by treatment with a solution of $0.05 \%$ trypsin (Sigma) and $0.02 \%$ EDTA (Sigma) and subsequently washed, and suspended in PBS and prepared for the study of cell cycle as reported by García-Martínez et al. [15]. The suspension obtained was placed in $200 \mu \mathrm{L}$ PBS with $2 \mathrm{~mL}$ ice-cold $70 \%$ ethanol and $30 \%$ distilled $\mathrm{H}_{2} \mathrm{O}$ and then vigorously mixed. Cells were left for at least $30 \mathrm{~min}$. in the cold and then harvested by centrifugation and resuspended in $800 \mu \mathrm{L}$ PBS. Cells were microscopically examined and, if clumped, passed through a 25-gauge syringe needle. Cells were then incubated at $37^{\circ} \mathrm{C}$ for $30 \mathrm{~min}$. with $100 \mu \mathrm{L}$ ribonuclease (RNase) $(1 \mathrm{mg} / \mathrm{mL})$ and $100 \mu \mathrm{L}$ propidium iodide (PI). Finally, samples were analyzed by using an argon-ion laser tuned to $488 \mathrm{~nm}$ (Fasc Vantage Becton Dickinson), measuring forward and orthogonal light scatter and red fluorescence, determining both area and Esther peak of the fluorescent signal.

2.4. Apoptosis and Necrosis Analysis. Cultured human MG63 osteosarcoma cells treated with $1,10,20,100$, or $1000 \mu \mathrm{M}$ aspirin for $12 \mathrm{~h}$ and untreated control cells were detached from the culture flask, washed and suspended in $300 \mu \mathrm{L} \mathrm{PBS}$ and then labelled with annexin V and PI (Immunostep S.L., Salamanca, Spain). We incubated $100 \mu \mathrm{L}$ aliquots of the cell suspension with $5 \mu \mathrm{L}$ annexin $\mathrm{V}$ and $5 \mu \mathrm{L}$ PI for $30 \mathrm{~min}$. at $4^{\circ} \mathrm{C}$ in the dark. Cells were then washed, suspended in $1 \mathrm{~mL}$ PBS, and immediately analyzed in a flow cytometer with argon laser (Fasc Vantage Becton Dickinson, Palo Alto, CA) at a wavelength of $488 \mathrm{~nm}$ to determine the percentage of fluorescent cells. Given that negative and positive controls

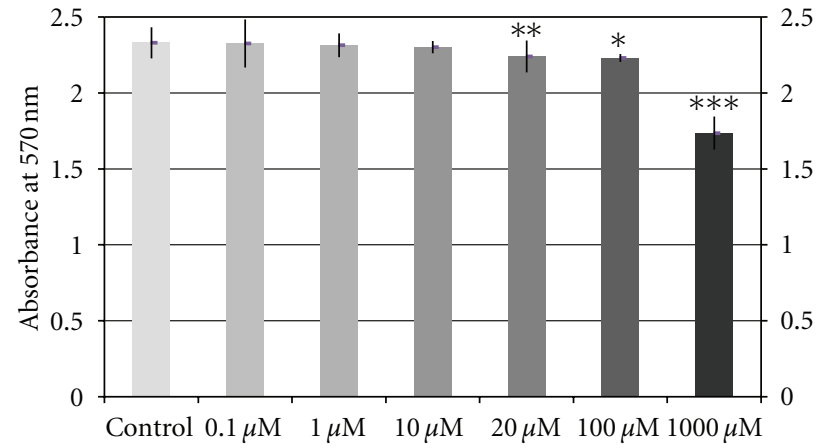

FIGURE 1: Effects of different aspirin doses $(0.1 \mu \mathrm{M}, 1 \mu \mathrm{M}, 10 \mu \mathrm{M}$, $20 \mu \mathrm{M}, 100 \mu \mathrm{M}$, or $1000 \mu \mathrm{M}$ ) on osteoblast proliferation in MG-63 cell line after $24 \mathrm{~h}$ of incubation. Data are expressed as means + SEM. We compared data between each treatment and control culture by analysis of variance (ANOVA) test. ${ }^{*} P=0.023$, ${ }^{* *} P=$ $0.014,{ }^{* * *} P=0.001$.

were included, we calculated the percentage of annexinpositive (apoptotic) cells and PI-positive (necrotic) cells from 2000-3000 cell counts.

2.5. Statistical Analysis. R software (version 2.9.2, Auckland, New Zealand) was used for data analysis. Mean values ( \pm standard deviation) were calculated for each variable. A two-way repeated-measures analysis of variance (ANOVA) was performed to examine the effects on proliferation, cell cycle, and apoptosis/necrosis induction, considering treatment (aspirin), time $(24 \mathrm{~h})$, and concentration $(0.1,1$, $10,20,100$, or $1000 \mu \mathrm{M})$. When a significant interaction was identified, the Bonferroni correction was applied for planned pair-wise comparisons. $P<0.05$ was considered significant. At least three experiments were performed for each culture.

\section{Results}

3.1. Effect of Aspirin Treatment on Mg-63 Cell Line Proliferation. No significant effect on MG-63 proliferation $(P>0.05)$ was observed after $24 \mathrm{~h}$ treatment at any of the assayed doses $(0.1,1$, and $10 \mu \mathrm{M}$ aspirin). However, significant adverse effect on cell growth was observed after treatment for $24 \mathrm{~h}$ at aspirin doses of $20 \mu \mathrm{M}(P=0.014), 100 \mu \mathrm{M}(P=0.023)$, and $1000 \mu \mathrm{M}(P=0.001)$ (Figure 1$)$.

3.2. Cell Cycle Study. The percentage of cells in each cell cycle phase (G0/G1, G2/M and S) was determined by flow cytometry. Table 1 and Figure 2 depict the results of the cell cycle study. No significant effect on MG-63 cell cycle $(P>$ 0.05 ) was observed after treatment for $24 \mathrm{~h}$ with 1,10 , or $20 \mu \mathrm{M}$ doses of aspirin. However, the cell percentage in $\mathrm{G}_{0} / \mathrm{G}_{1}$ phase was significantly increased by treatment at doses of 100 and $1000 \mu \mathrm{M}(P<0.001)$. The mean percentage cell count in $\mathrm{G}_{0} / \mathrm{G}_{1}$ phase was 42.68 in control cultures versus 54.38 in $100 \mu \mathrm{M}$-treated and 77.44 in $1000 \mu \mathrm{M}$-treated cultures. 
TABLe 1: Numerical data for cell cycle fluorescence profile of MG-63 cells in culture treated for $24 \mathrm{~h}$ with aspirin doses of 1, 10, 20, 100, or $1000 \mu \mathrm{M}$.

\begin{tabular}{|c|c|c|c|c|c|c|}
\hline & \multicolumn{2}{|c|}{ G0-G1 } & \multicolumn{2}{|c|}{ G2-M } & \multicolumn{2}{|c|}{ S } \\
\hline & Mean & $P$ value & Mean & $P$ value & Mean & $P$ value \\
\hline Control & $44.34(2.79)$ & - & $27.22(0.57)$ & - & $30.09(0.07)$ & - \\
\hline Aspirin $1 \mu \mathrm{M}$ & $42.34(2.63)$ & 0.46 & $26.41(2.26)$ & 0.58 & $31.02(0.41)$ & 0.07 \\
\hline Aspirin $10 \mu \mathrm{M}$ & $42.21(5.25)$ & 0.5 & $24.85(3.74)$ & 0.3 & $32.94(2.48)$ & 0.1 \\
\hline Aspirin $20 \mu \mathrm{M}$ & $41.54(2.16)$ & 0.24 & $27.52(0.60)$ & 0.57 & $30.93(1.75)$ & 0.47 \\
\hline Aspirin $100 \mu \mathrm{M}$ & $54.38(1.79)$ & $0.006^{*}$ & $20.94(1.35)$ & $0.002^{*}$ & $24.68(2.96)$ & 0.03 \\
\hline Aspirin $1000 \mu \mathrm{M}$ & $77.44(0.83)$ & $0.0001^{*}$ & $5.95(1.15)$ & $0.0001^{*}$ & $16.60(1.93)$ & $0.0001 *$ \\
\hline
\end{tabular}

* Significant differences.

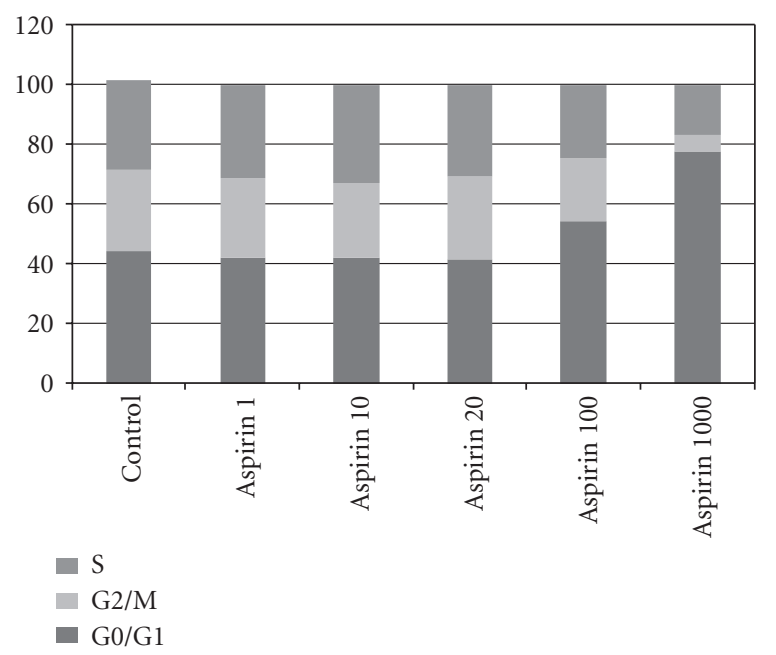

FIGURE 2: Effects of aspirin on cell cycle kinetics of MG-63 cell line determined by flow cytometry. Cultured cells were treated for $24 \mathrm{~h}$ with $1,10,20,100$, or $1000 \mu \mathrm{M}$ aspirin. Control group was not treated. G0/G1, S, and G2/M represent the percentage of cells distributed among these phases after treatment, as determined by flow cytometry. We repeated experiments at least three times.

3.3. Apoptosis. Annexin V and PI were used to further discriminate apoptotic cell death from necrotic cell death in the cell cycle. Table 2 and Figure 3 show results of one experiment after culture for $12 \mathrm{~h}$, as an example. The number of viable cells $\left(\mathrm{Ann} \mathrm{V}^{-}, \mathrm{PI}^{-}\right.$) was counted in the lower left quadrant $(\mathrm{Q} 3)$ of density plots, and the percentages of cells in early apoptosis $\left(\mathrm{Ann} \mathrm{V}^{+}, \mathrm{PI}^{-}\right.$, lower right quadrant Q4), late apoptosis (Ann $\mathrm{V}^{+}, \mathrm{PI}^{+}$, upper right quadrant Q2), and necrosis (Ann $\mathrm{V}^{-}, \mathrm{PI}^{+}$, upper left quadrant Q1) were determined. Figure 3 shows the cell percentage in each quadrant after $12 \mathrm{~h}$ exposure to aspirin at different doses. No significant effect was found on the cell percentage in any quadrant after treatment for $12 \mathrm{~h}$ at doses of 1 and $10 \mu \mathrm{M}$ aspirin. In contrast, a significant increase in cell percentage was observed versus controls in early apoptosis (8.31 versus $3.71 \%, P=0.043)$ and late apoptosis (14.69 versus $2.84 \%$, $(P<0.001)$ after $12 \mathrm{~h}$ treatment with a $20 \mu \mathrm{M}$ dose, finding a significant reduction in living cells in the treated group versus controls $(69.59 \%$ versus $89.82 \%, P=0.012)$. After

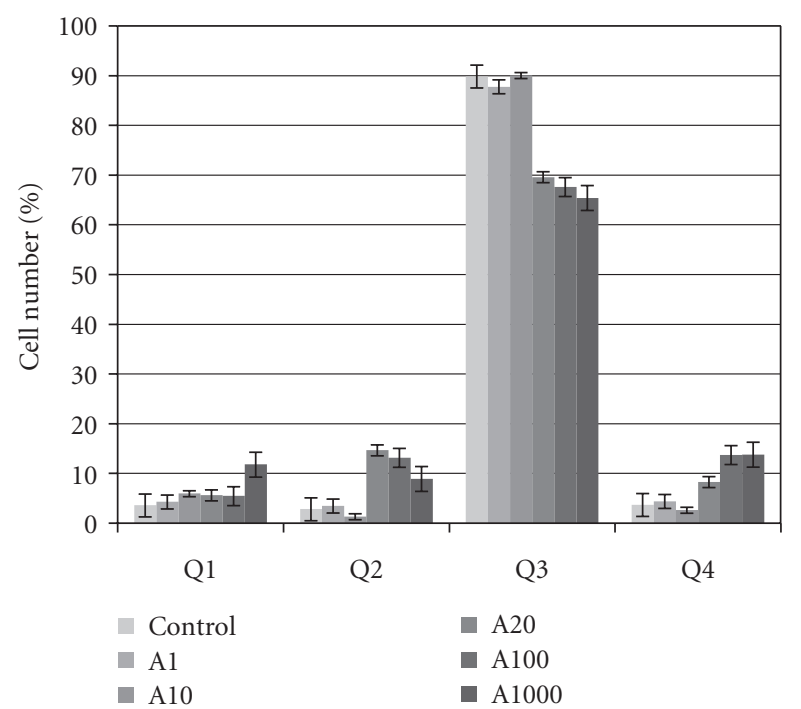

FIGURE 3: Percentage of Annexin V binding and propidium iodide uptake of MG63 cells after culture for $12 \mathrm{~h}$. Q1 (necrosis: Ann $\mathrm{V}^{-}$, $\mathrm{PI}^{+}$), Q2 (late apoptosis: Ann $\mathrm{V}^{+}, \mathrm{PI}^{+}$), Q3 (viable cells: Ann $\mathrm{V}^{-}$, $\mathrm{PI}^{-}$), and Q4 (early apoptosis: Ann $\mathrm{V}^{+}, \mathrm{PI}^{-}$). Data are means \pm standard deviation of at least three independent determinations.

$12 \mathrm{~h}$ treatment with $100 \mu \mathrm{M}$ aspirin, the cell percentage in early apoptosis increased by $13.74 \%(P=0.002$ versus controls) and the percentage in late apoptosis by $13.18 \%$ ( $P=0.0092$ versus controls) and there was a reduction of $67.61 \%$ in living cells ( $P=0.001$ versus controls). After 12 h treatment with $1000 \mu \mathrm{M}$ aspirin, cell percentage in early apoptosis increased by $13.82 \%(P=0.001$ versus controls $)$, the percentage in late apoptosis increased by $13.18 \%(P=$ 0.0092 ), and the percentage of necrotic cells increased by $11.81 \%(P=0.001)$, and there was a $65.41 \%$ decrease in living cells $(P=0.002)$.

\section{Discussion}

The anti-inflammatory properties of NSAIDs, including aspirin, derive from their powerful inhibitory effects on cyclooxygenase metabolites such as prostaglandin E2 [16]. Consequently, some authors attribute the adverse effect 
TABle 2: Numerical data for the percentage annexin V binding and propidium iodide uptake of MG63 cells after culture for 12 h. Q1 (necrosis: Ann $\mathrm{V}^{-}, \mathrm{PI}^{+}$), Q2 (late apoptosis: Ann $\mathrm{V}^{+}, \mathrm{PI}^{+}$), Q3 (viable cells: Ann $\mathrm{V}^{-}, \mathrm{PI}^{-}$), Q4 (early apoptosis: Ann $\mathrm{V}^{+} \mathrm{PI}^{-}$). Data are means \pm standard derivation of at least three independent determinations.

\begin{tabular}{|c|c|c|c|c|c|}
\hline & & MEAN & SD & $P$ & C.I. $(95 \%)$ \\
\hline \multirow{4}{*}{ Control } & Necrosis & 3.61 & 1.6163 & - & - \\
\hline & Late Ap. & 2.84 & 1.4530 & - & - \\
\hline & Negative & 89.82 & 4.2866 & - & - \\
\hline & Apoptosis & 3.71 & 1.9480 & - & - \\
\hline \multirow{4}{*}{$\mathrm{A} 1 \mu \mathrm{M}$} & Necrosis & 9.31 & 0.5695 & 0.005 & $-8.4471 ;-2.9528$ \\
\hline & Late Ap. & 8.16 & 0.4923 & 0.004 & $-7.7793 ;-2.8606$ \\
\hline & Negative & 73.09 & 0.3157 & 0.021 & $6.1649 ; 27.3016$ \\
\hline & Apoptosis & 9.42 & 0.3005 & 0.007 & $-8.8695 ;-2.5504$ \\
\hline \multirow{4}{*}{$\mathrm{A} 10 \mu \mathrm{M}$} & Necrosis & 5.97 & 0.5697 & 0.076 & $-5.1072 ; 0.3872$ \\
\hline & Late Ap. & 1.3467 & 0.2514 & 0.213 & $-1.9720 ; 4.9720$ \\
\hline & Negative & 90.0267 & 1.3050 & 0.941 & $-7.3861 ; 6.9794$ \\
\hline & Apoptosis & 2.6533 & 0.6192 & 0.421 & $-2.2166 ; 4.3332$ \\
\hline \multirow{4}{*}{$\mathrm{A} 20 \mu \mathrm{M}$} & Necrosis & 5.64 & 1.4516 & 0.182 & $-5.5058 ; 1.4592$ \\
\hline & Late Ap. & 14.69 & 0.4531 & 0.000 & $-14.2832 ;-9.4034$ \\
\hline & Negative & 69.59 & 0.8826 & 0.012 & $10.1319 ; 30.3281$ \\
\hline & Apoptosis & 8.31 & 1.8938 & 0.043 & $-8.9583 ;-0.2482$ \\
\hline \multirow{4}{*}{$\mathrm{A} 100 \mu \mathrm{M}$} & Necrosis & 5.48 & 1.4807 & 0.215 & $-5.3772 ; 1.6505$ \\
\hline & Late Ap. & 13.18 & 2.1219 & 0.002 & $-14.4558 ;-6.2108$ \\
\hline & Negative & 67.61 & 2.3404 & 0.001 & $14.3844 ; 30.0422$ \\
\hline & Apoptosis & 13.74 & 3.0390 & 0.009 & $-15.8230 ;-4.2502$ \\
\hline \multirow{4}{*}{$\mathrm{A} 1000 \mu \mathrm{M}$} & Necrosis & 11.81 & 1.5383 & 0.003 & $-11.7735 ;-4.6197$ \\
\hline & Late Ap. & 8.94 & 3.2706 & 0.042 & $-11.8335 ;-0.3597$ \\
\hline & Negative & 65.41 & 3.5840 & 0.002 & $15.4499 ; 33.3633$ \\
\hline & Apoptosis & 13.82 & 1.0186 & 0.001 & $-13.6404 ;-6.5929$ \\
\hline
\end{tabular}

of NSAIDs on osteoblasts to a reduced synthesis of prostaglandins, which act as bone cell growth factors, as a result of the inhibition of cyclooxygenase enzymes [17]. However, there is some controversy concerning the adverse effect of NSAIDs on osteoblast growth $[10,18]$. The disparate results obtained may be due to multiple factors, including dosage, treatment duration, and the species in question $[13,17]$.

In this study, the proliferative capacity of cells from the MG-63 cell line was not significantly inhibited by $24 \mathrm{~h}$ treatment with $0.1,1$, or $10 \mu \mathrm{M}$ aspirin but was significantly inhibited by $24 \mathrm{~h}$ treatment with 20,100 , and $1000 \mu \mathrm{M}$ aspirin. Therefore, this NSAID does not have an adverse effect on bone cell proliferation in vitro at the therapeutic dose range used in the clinical setting ( 1 to $10 \mu \mathrm{M}$ ). It was previously reported that the dose of NSAIDs is a key factor in the effect on cell proliferation as well as on cell differentiation and migration [19].

The effect of different doses on the growth of the MG63 line is closely related to the effects observed on the cell cycle. Thus, the negative effect on growth at 100 and $1000 \mu \mathrm{M}$ aspirin may be explained by the significant increase in the percentage of cells in phase G0/G1 versus the control group. Ann V and PI staining showed that the reduced cell growth at 20 and $100 \mu \mathrm{M}$ doses was attributable to apoptosis rather than necrosis. In contrast, treatment with a $1000 \mu \mathrm{M}$ produced an increase in necrotic cells as well as cells in apoptosis.

We highlight that treatment of the MG63 line with therapeutic doses of aspirin $(1-10 \mu \mathrm{M})$ did not cause cell death, cell cycle changes, or modifications in apoptosis/necrosis induction. In contrast, therapeutic doses of ketorolac, indomethacin, or diclofenac induced cell death in osteoblast cultures from rat foetal calvaria and may suppress bone formation and impair bone remodelling by cell cycle arrest in $G_{0} / G_{1}$ phase $[9,10]$. In another in vitro study, 24 $\mathrm{h}$ treatment with indomethacin or nimesulide at therapeutic doses also reduced osteoblast growth capacity and produced significant changes in the cell cycle, which was again arrested in $\mathrm{G}_{0} / \mathrm{G}_{1}$ phase [12].

A recent cohort study of subjects exposed and not exposed to NSAIDs and opioids observed no difference in bone mineral density over time but reported excessive risk of fractures in users of some NSAIDs, although not in those receiving aspirin [20]. These results are consistent with the present in vitro data.

Furthermore, another important aspect of aspirin, from a clinical standpoint, is that when the lipoxin pathway 
is activated in the presence of aspirin, acetylation of the cyclooxygenase 2 enzyme present at inflammation sites not only inhibits further production of prostanoids, but also induces the synthesis of 15-hydroxyeicosatetraenoic acid, which is then transformed into 5(S)-epoxytetraene in leukocytes in the presence of 5-lipoxygenase. The 5(S)epoxytetraene intermediate is then transformed to 15epilipoxins or aspirin-triggered lipoxins, which are more bioactive than native lipoxins and have more powerful resolving properties $[21,22]$.

In conclusion, aspirin at therapeutic doses appears to have no adverse effect on osteoblast growth, unlike some other NSAIDs. Growth was only reduced at higher doses, by cell cycle arrest and apoptosis induction. These findings support the use of aspirin in the treatment of inflammation and pain in bone lesions requiring tissue regeneration. Given reports that indomethacin and diclofenac can increase cell adhesion and reduce the migration of different cell populations [23-25], further research is warranted to determine whether aspirin may exert action on the cell adhesion or migration of osteoblasts, other key factors in the regenerative process.

\section{Acknowledgments}

This study was supported by research group BIO277 (Junta de Andalucía) and by the Department of Nursing of the Health Sciences School of the University of Granada.

\section{References}

[1] A. Beck, G. Krischak, T. Sorg et al., "Influence of diclofenac (group of nonsteroidal anti-inflammatory drugs) on fracture healing," Archives of Orthopaedic and Trauma Surgery, vol. 123, no. 7, pp. 327-332, 2003.

[2] L. C. Gerstenfeld, M. Thiede, K. Siebert et al., "Differential inhibition of fracture healing by non-selective and cyclooxygenase-2 selective non-steroidal anti-inflammatory drugs," Journal of Orthopaedic Research, vol. 21, no. 4, pp. 670675, 2003.

[3] C. E. Evans and C. Butcher, "The influence on human osteoblasts in vitro on non-steroidal anti-inflammatory drugs which act on different cyclooxygenase enzymes," Journal of Bone and Joint Surgery B, vol. 86, no. 3, pp. 444-449, 2004.

[4] D. Kaspar, C. M. Hedrich, C. Schmidt, A. Liedert, L. E. Claes, and A. A. Ignatius, "Diclofenac inhibits proliferation and matrix formation of osteoblast cells," Unfallchirurg, vol. 108, no. 1, pp. 18-24, 2005.

[5] T. Naruse, Y. Nishida, K. Hosono, and N. Ishiguro, "Meloxicam inhibits osteosarcoma growth, invasiveness and metastasis by COX-2-dependent and independent routes," Carcinogenesis, vol. 27, no. 3, pp. 584-592, 2006.

[6] G. D. Krischak, P. Augat, R. Blakytny, L. Claes, L. Kinzl, and A. Beck, "The non-steroidal anti-inflammatory drug diclofenac reduces appearance of osteoblasts in bone defect healing in rats," Archives of Orthopaedic and Trauma Surgery, vol. 127, no. 6, pp. 453-458, 2007.

[7] K. Yoshida, H. Oida, T. Kobayashi et al., "Stimulation of bone formation and prevention of bone loss by prostaglandin E EP4 receptor activation," Proceedings of the National Academy of Sciences of the United States of America, vol. 99, no. 7, pp. 4580$4585,2002$.
[8] X. H. Liu, A. Kirschenbaum, S. Yao, and A. C. Levine, "Crosstalk between the interleukin- 6 and prostaglandin E2 signaling systems results in enhancement of osteoclastogenesis through effects on the osteoprotegerin/receptor activator of nuclear factor- $\kappa$ B (RANK) ligand/RANK system," Endocrinology, vol. 146, no. 4, pp. 1991-1998, 2005.

[9] J. K. Chang, G. J. Wang, S. T. Tsai, and M. L. Ho, "Nonsteroidal anti-inflammatory drug effects on osteoblastic cell cycle, cytotoxicity, and cell death," Connective Tissue Research, vol. 46, no. 4-5, pp. 200-210, 2005.

[10] J. K. Chang, C. J. Li, H. J. Liao, C. K. Wang, G. J. Wang, and M. L. Ho, "Anti-inflammatory drugs suppress proliferation and induce apoptosis through altering expressions of cell cycle regulators and pro-apoptotic factors in cultured human osteoblasts," Toxicology, vol. 258, no. 2-3, pp. 148-156, 2009.

[11] L. Díaz-Rodríguez, O. García-Martínez, M. Arroyo-Morales, B. Rubio-Ruiz, and C. Ruiz, "Effect of acetaminophen (paracetamol) on human osteosarcoma cell line MG63," Acta Pharmacologica Sinica, vol. 31, no. 11, pp. 1495-1499, 2010.

[12] L. Díaz-Rodríguez, O. García-Martínez, M. Arroyo-Morales, L. Rodríguez-Pérez, B. Rubio-Ruiz, and C. Ruiz, "Effects of indomethacin, nimesulide, and diclofenac on human MG-63 osteosarcoma cell line," Biological Research For Nursing, vol. 14, no. 1, pp. 98-107, 2012.

[13] P. Arpornmaeklong, S. H. Lee, C. Ohkubo, B. Akarawatcharangura, and P. Pripatnanont, "Factors influencing effects of specific COX-2 inhibitor NSAIDs on growth and differentiation of mouse osteoblasts on titanium surfaces," International Journal of Oral and Maxillofacial Implants, vol. 23, no. 6, pp. 1071-1081, 2008.

[14] L. Díaz-Rodríguez, O. García-Martínez, M. Arroyo-Morales, C. Reyes-Botella, and C. Ruiz, "Antigenic phenotype and phagocytic capacity of MG-63 osteosarcoma line," Annals of the New York Academy of Sciences, vol. 1173, no. 1, pp. E46E54, 2009.

[15] O. García-Martínez, L. Díaz-Rodríguez, L. Rodríguez-Pérez, E. de Luna-Bertos, C. Reyes-Botella, and C. Ruiz, "Effect of platelet-rich plasma on primary cultured human osteoblastlike cells," Archives of Oral Biology, vol. 56, pp. 317-323, 2011.

[16] W. L. Smith, D. L. DeWitt, and R. M. Garavito, "Cyclooxygenases: structural, cellular, and molecular biology," Annual Review of Biochemistry, vol. 69, pp. 145-182, 2000.

[17] P. Salari and M. Abdollahi, "Controversial effects of nonsteroidal anti-inflammatory drugs on bone: a review," Inflammation and Allergy - Drug Targets, vol. 8, no. 3, pp. 169-175, 2009.

[18] H. Abukawa, M. Phelps, P. Jackson et al., "Effect of Ibuprofen on Osteoblast Differentiation of Porcine Bone MarrowDerived Progenitor Cells," Journal of Oral and Maxillofacial Surgery, vol. 67, no. 11, pp. 2412-2417, 2009.

[19] M. Müller, O. Raabe, K. Addicks, S. Wenisch, and S. Arnhold, "Effects of non-steroidal anti-inflammatory drugs on proliferation, differentiation and migration in equine mesenchymal stem cells," Cell Biology International, vol. 35, no. 3, pp. 235248, 2011.

[20] P. Vestergaard, P. Hermann, J.-E. B. Jensen, P. Eiken, and L. Mosekilde, "Effects of paracetamol, non-steroidal antiinflammatory drugs, acetylsalicylic acid, and opioids on bone mineral density and risk of fracture: results of the Danish osteoporosis prevention study (DOPS)," Osteoporosis International. In press.

[21] R. Flower, "What are all the things that aspirin does? This fascinating but simple and cheap drug has an assured future," British Medical Journal, vol. 327, no. 7415, pp. 572-573, 2003. 
[22] T. E. van Dyke and C. N. Serhan, "Resolution of inflammation: a new paradigm for the pathogenesis of periodontal diseases," Journal of Dental Research, vol. 82, no. 2, pp. 82-90, 2003.

[23] L. L. Martinez, M. A. Oliveira, A. Silvia Miguel et al., "Losartan attenuates the antimigratory effect of diclofenac in spontaneously hypertensive rats," Journal of Cardiovascular Pharmacology, vol. 46, no. 2, pp. 190-199, 2005.

[24] H. Axelsson, C. Lönnroth, M. Andersson, and K. Lundholm, "Mechanisms behind COX-1 and COX-2 inhibition of tumor growth in vivo," International Journal of Oncology, vol. 37, no. 5, pp. 1143-1152, 2010.

[25] N. Villalonga, M. David, J. Bielańska et al., "Immunomodulatory effects of diclofenac in leukocytes through the targeting of Kv1.3 voltage-dependent potassium channels," Biochemical Pharmacology, vol. 80, no. 6, pp. 858-866, 2010. 

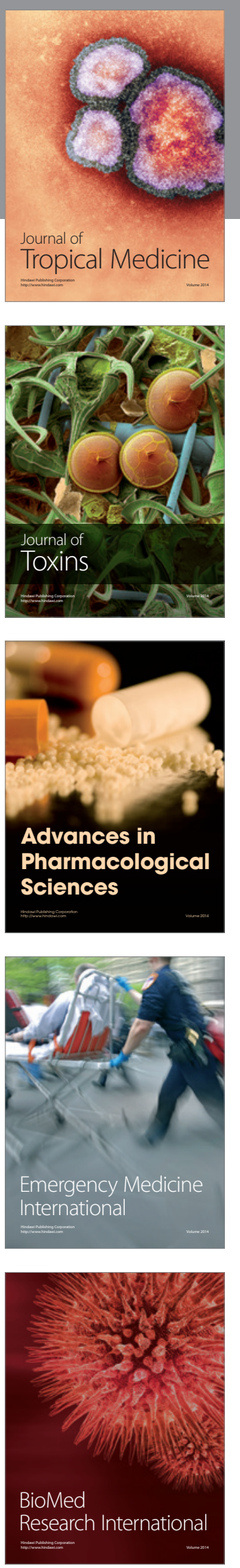
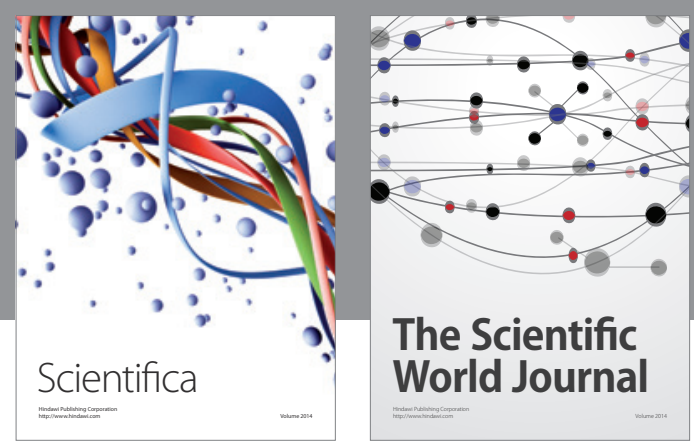

The Scientific World Journal
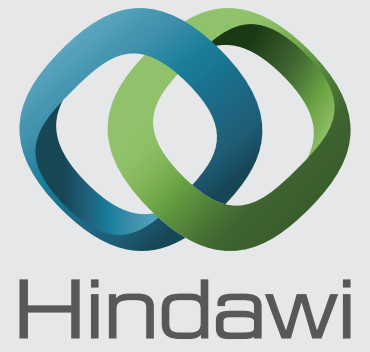

Submit your manuscripts at

http://www.hindawi.com
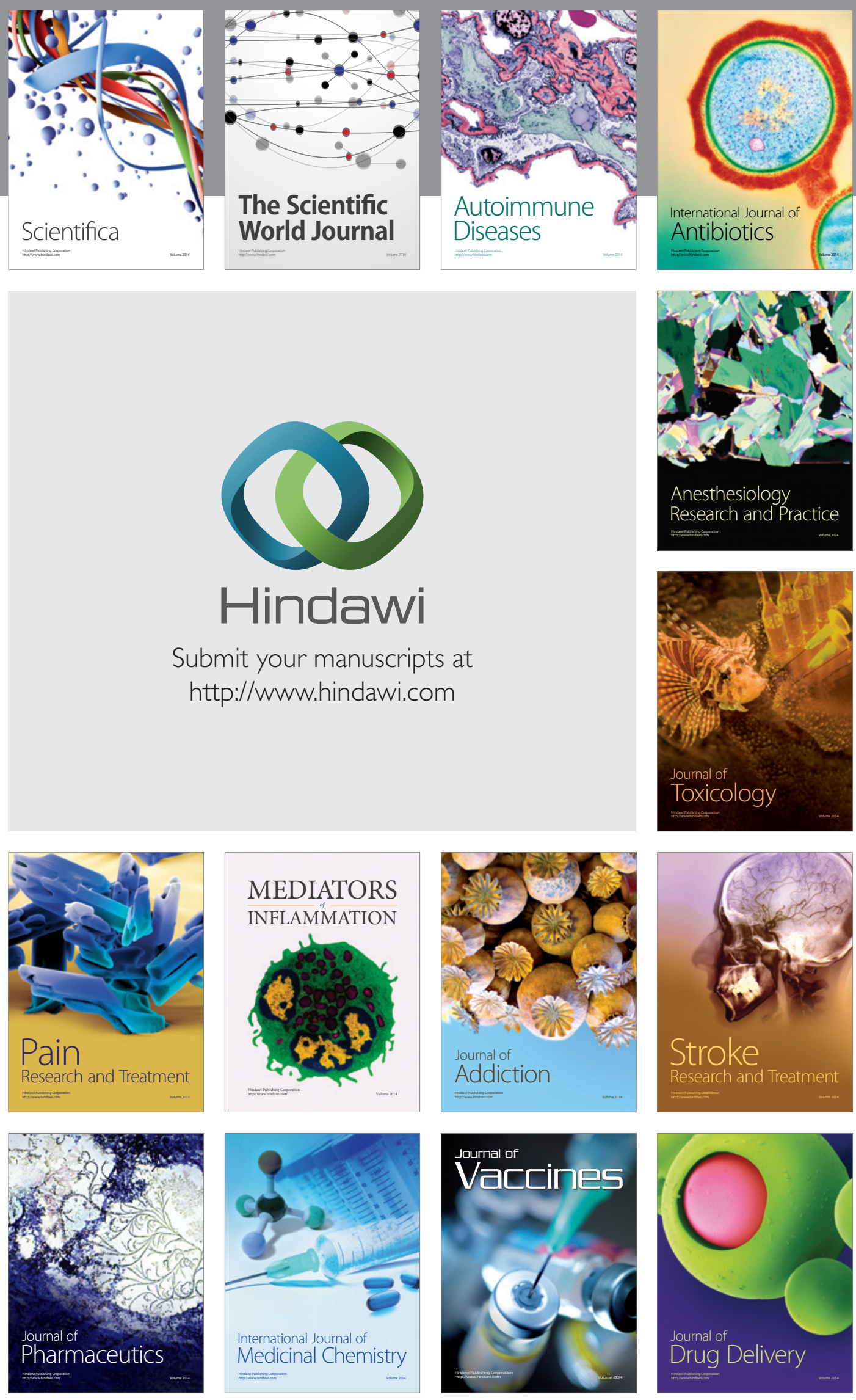